\title{
Editorial
}

\section{An Overview of Trends and Challenges in Higher Education on the Worldwide Research Agenda}

\author{
Elena Tikhonova \\ National Research University Higher School of Economics; \\ Peoples' Friendship University of Russia (RUDN University) \\ Correspondence concerning this article should be addressed to Elena Tikhonova, National Research \\ University Higher School of Economics, 26 Shabolovka, Moscow, Russian Federation, 119049. \\ E-mail: etihonova@hse.ru \\ Lilia Raitskaya \\ Moscow State Institute of International Relations (MGIMO University) \\ Correspondence concerning this article should be addressed to Lilia Raitskaya, MGIMO University, 76 Pr. \\ Vernadskogo, Moscow, Russia, 119454.E-mail: raitskaya.1.k@inno.mgimo.ru
}

\begin{abstract}
Being a crucial part of the JLE scope, higher education is witnessing an era of supra-national, national, and institutional changes, including massification via massive online open courses (MOOC), politically launched or influenced trends like the Bologna process, increasing academic mobility spurred by globalisation and continued development of internationalised education, interculturality and multiligualism, worldwide innovations in higher education and teaching approaches (deep active learning, blended learning methods, gamification, storytelling, alignments of higher education and work, translanguaging in higher education instruction). Further, the JLE editors dwell upon other relevant issues, including transformation of universities, student-teacher relationship, social equity and access to higher education, students' engagement and commitment to learning, university excellence factors.

The editorial entails some guidelines for potential authors regarding priority themes JLE is going to promote within its scope.
\end{abstract}

Keywords: higher education, educational reforms, blended learning, learner autonomy, quality of higher education, active learning, flipped classroom, innovations in education, translanguaging

Present-day transformation of higher education systems, emerging pressures of dramatic limitation of public funding and issues related to the massification of higher education round the globe lead to a transfigured research agenda. With a few eternal themes staying in place, a new swathe of topics are coming to the fore.

Most countries are currently involved in all kinds of higher education reforms. A lot of studies are focused on different aspects of those reforms: starting from neo-liberal foundation and approaches to higher education (Gerrard, 2015; Zepke, 2018), universities' striving for excellence and competitiveness (Mok, 2015; Hostings, 2015; Song, 2018), country-related reform specialities (Coome, 2015; Noyes \& Adkins, 2016) to quality revolution in tertiary education
(Minina, 2017), re-defining quality of higher education and its factors (Little, 2015; Cheng, 2017; Scharager, Goldenberg, 2018), and pitfalls it faces (Cardoso, Rosa, \& Stensaker, 2016). Another popular research niche embraces world university rankings encouraging university transformation into cost-centres with destroyed or distorted primary missions of universities in the society (Brankovic et al., 2018; McCoy et al., 2018; Milian \& Rizk, 2018) or, quite on the opposite, into institutions of excellence.

University rankings form an integral part of knowledge economy as a tool of quantitative quality assessment in higher education. They aim to single out the advantages and strengths of the leading world or regional universities and reshape enrolment processes at universities. Some researchers show that 
students do not tend to consult ranking publications, relying often 'on reputational information available through their informal networks' (Milian \& Rizk, 2018). Rankings influence both educational policy and higher education reforms. With much constructive or blunt criticism and concerns around, university rankings, their methodology, and negative institutional outcomes need further research.

Reforms in higher education ought to be studied within the contexts of globalisation and internationalisation. The former have led to massification in tertiary education via MOOCs, distance learning, and e-learning. It is widely articulated in the literature that massification transforms higher education institutions (Literat, 2015; Akalu, 2016). New challenges and pitfalls relating to massification in higher education cover a paucity of resources for MOOCs, increased workload for the academia at large, partial loss of autonomy for the professoriate, declining quality of education by various criteria (Akalu, 2016). More studies of MOOCs as a social framework enabling a lifelong learning context are beginning to appear.

There is a growing gap between academic and student understandings of education quality (Strielkowski, Kiseleva \& Popova, 2018). Moreover, employers tend to expect other sets of skills their future hires to acquire, with social skills being at the top of their wish lists. Social skills, communication skills, employability skills, soft skills and other sets are under academic and research scrutiny worldwide. This direction seems very promising in the light of fierce competition on world and national labour markets.

The inverted or so-called 'flipped' classroom approach has been thoroughly parsed for about a decade. The concept of 'self-studies via technologybased resources (called 'flips')' (Lundin et al., 2018) followed by comprehensive in-class activities has gained popularity at all levels of education. Higher education curricula massively introduce this approach into both bachelor and master programmes. More papers address some chasms in research on flipped classroom method by reporting advantages and weaknesses, techniques, approaches, motivation assessment (Nikitina, Don, \& Cheong, 2016) and results (Akçayır \& Akçayır, 2018; Lundin et al., 2018; Zainuddin \& Perera, 2019).

Higher education policy throughout the world is influenced by political and economic considerations. Some trends in education may be defined as mainly policy-related, e.g. the Bologne process. In Europe, the phenomenon is under a new re-thinking (Leisyte, Zelvys, \& Zenkiene, 2015; Ala-Vähälä, 2016), with more research on quality of higher education within increasing academic mobility environment (Baker, 2018; Morley et al., 2018; Siekierski et al., 2018). As the historic developments prove, the process initially aimed to support regional (mainly Eastern European) and small-scale universities in their aligning with the best European universities. Intense academic mobility in EU universities enhances university cooperation and unification of curricula, but poses challenges to quality and traditional approaches and teaching methods.

Though active learning emerged as a research domain in the early 1990s, at present, quite a lot of studies raise issues of case study method, role-playing, gamification, and simulation in higher education (Aparicio et al., 2019; Gatt et al., 2019). Gamification and other active learning methods are widely considered in research to be algorithms associated with 'learner interaction ... and positive experience of MOOCs' (Aparicio et al., 2019). In addition, research on deep learning and deep active learning (Engel, Pallas, \& Lambert, 2017; Hermes \& Rimaniroczy, 2018) come out regularly. Researchers in the neighbouring social fields (education, psychology, applied linguistics, sociology, philosophy) approach social phenomena via a mix of stances and methods, often interdisciplinary at heart. Future research focus is certain to lie within the social science domain, but new interdisciplinary shifts and complex intradisciplinary accents may turn up. Gaps in understanding of the new higher education landscape and its phenomena cannot but arise as a part of the impending research agenda.

Higher education and progressive learning methods have much overlapping with the concept of learner autonomy and self-regulation (Hartley et al., 2016; Hawe \& Dixon, 2017). The latter lay foundation for research on lifelong learning and professional or academic development.

Learner autonomy is traditionally attached to language learning. Though it is widely discussed, autonomy is still studied as an educational goal in the contexts of learning styles and learner's personal traits, attitudes, and motivation (Schneider, 2018; Lan, 2018). More papers may be brought out with accents on autonomy of all academic players in various settings.

To end it up, one more priority area of research for JLE cannot be missed out. It is languages as a means of both instruction in higher education and communication in science and research. Often denominated lingua franca or interlingua in both science and education, English gave birth to new promising lines for researchers. Though, translanguaging dates back to the 1980s with its roots in Welsh bilingual education (Conteh, 2018), it is updated through the ways migration and mobility influence pedagogy and education in the globalised world. Scientific and academic literature published mainly in English essentially factors in the process. Some studies on translanguaging in higher education have come out recently to be followed by more focused on language policies, student - teacher relationship, 
curricula, and assessment issues (Caruso, 2018; Conteh, 2018).

In research, authors have recently turned to scientific imperialism (Popova \& Beavitt, 2017), English as lingua franca in science, English for publication or research purposes (Li, Flowerdew, \& Cargill, 2018), English as an intercultural language (Lee, 2018), English vs multilingualism, and other brand-new or revised themes.

Academics worldwide pursue heavy research agendas in the afore-mentioned directions, with JLE being no exception. We hope that the outlined themes may prompt our potential authors to plunge into comprehensive research and share their results with our readers.

\section{References}

Akalu, G. A. (2016). Higher education 'massification' and challenges to the professoriate: Do academics' conceptions of quality matter? Quality in Higher Education, 22(3), 260-276. doi:10.1080/13538322.2 016.1266230

Akçayır, G., \& Akçayır, M. (2018). The flipped classroom: A review of its advantages and challenges. Computers and Education, 126, 334-345. doi:10.1016/j.compedu.2018.07.021

Ala-Vähälä, T. (2016). Reception of the quality assurance commitments of the Bologna process in Finnish higher education institutions. Quality in Higher Education, 22(2), 103-116. doi:10.1080/1353 8322.2016.1195966

Aparicio, M., Oliveira, T., Bacao, F., \& Painho, M. (2019). Gamification: A key determinant of massive open online course (MOOC) success. Information and Management, 56(1), 39-54. doi:10.1016/j. im.2018.06.003

Baker, W. (2016). English as an academic lingua franca and intercultural awareness: Student mobility in the transcultural university. Language and Intercultural Communication, 16(3), 437-451. doi:10 $.1080 / 14708477.2016 .1168053$

Brankovic, J., Ringel, L., \& Werron, T. (2018). How rankings produce competition: The case of global university rankings. Zeitschrift Fur Soziologie, 47(4), 270-288. doi:10.1515/zfsoz-2018-0118

Cardoso, S., Rosa, M. J., \& Stensaker, B. (2016). Why is quality in higher education not achieved? The view of academics. Assessment and Evaluation in Higher Education, 41(6), 950-965. doi:10.1080/02602938.2 015.1052775

Caruso, E. (2018). Translanguaging in higher education: Using several languages for the analysis of academic content in the teaching and learning process. Language Learning in Higher Education, 8(1), 65-90. doi:10.1515/cercles-2018-0004

Cheng, M. (2017). Reclaiming quality in higher education: A human factor approach. Quality in Higher Education, 23(2), 153-167. doi:10.1080/1353 8322.2017.1358954

Conteh, J. (2018). Translanguaging. ELT Journal, 72(4), 445-447. doi:10.1093/elt/ccy034

Engel, S., Pallas, J., \& Lambert, S. (2017). Model United Nations and deep learning: Theoretical and professional learning. Journal of Political Science Education, 13(2), 171-184. doi:10.1080/15512169.2 016.1250644

Gatti, L., Ulrich, M., \& Seele, P. (2019). Education for sustainable development through business simulation games: An exploratory study of sustainability gamification and its effects on students' learning outcomes. Journal of Cleaner Production, 207, 667-678. doi:10.1016/i. jclepro.2018.09.130

Gerrard, J. (2015). Public education in neoliberal times: Memory and desire. Journal of Education Policy, 30(6), 855-868. doi:10.1080/02680939.2015 .1044568

Hartley, M., Gopaul, B., Sagintayeva, A., \& Apergenova, R. (2016). Learning autonomy: Higher education reform in Kazakhstan. Higher Education, 72(3), 277289. doi:10.1007/s10734-015-9953-z

Hawe, E., \& Dixon, H. (2017). Assessment for learning: A catalyst for student self-regulation. Assessment and Evaluation in Higher Education, 42(8), 11811192. doi:10.1080/02602938.2016.1236360

Hermes, J., \& Rimanoczy, I. (2018). Deep learning for a sustainability mindset. International Journal of Management Education, 16(3), 460-467. doi:10.1016/i.ijme.2018.08.001

Hostins, R. C. L. (2015). Evaluation policy in education: The effects of international standards and performativity on Brazil's postgraduate programmes of excellence. Journal of Education Policy, 30(3), 406-428. doi:10.1080/02680939.2014 .989277

Lan, Y. (2018). Technology enhanced learner ownership and learner autonomy through creation. Educational Technology Research and Development, 66(4), 859-862. doi:10.1007/s11423018-9608-8

Lee, K. (2018). For English not as an international but as an intercultural language among students in distribution science business English programs. Journal of Distribution Science, 16(11), 5-10. doi:10.15722/jds.16.11.201811.5

Leisyte, L., Zelvys, R., \& Zenkiene, L. (2015). Recontextualization of the Bologna process in Lithuania. European Journal of Higher Education, 5(1), 49-67. doi:10.1080/21568235.2014 
.951669

Li, Y., Flowerdew, J., \& Cargill, M. (2018). Teaching English for research publication purposes to science students in China: A case study of an experienced teacher in the classroom. Journal of English for Academic Purposes, 35, 116-129. doi:10.1016/j. jeap.2018.07.006

Literat, I. (2015). Implications of massive open online courses for higher education: Mitigating or reifying educational inequities? Higher Education Research and Development, 34(6), 1164-1177. doi:10.1080/07 294360.2015.1024624

Little, D. (2015). Guiding and modelling quality improvement in higher education institutions. Quality in Higher Education, 21(3), 312-327. doi:10.1080/13538322.2015.1111008

Lundin, M., Bergviken Rensfeldt, A., Hillman, T., Lantz-Andersson, A., \& Peterson, L. (2018). Higher education dominance and siloed knowledge: A systematic review of flipped classroom research. International Journal of Educational Technology in Higher Education, 15(1). doi:10.1186/s41239-0180101-6

McCoy, C. G., Nelson, M. L., \& Weigle, M. C. (2018). Mining the web to approximate university rankings. Information Discovery and Delivery, 46(3), 173-183. doi:10.1108/IDD-05-2018-0014

Milian, R. P., \& Rizk, J. (2018). Do university rankings matter? A qualitative exploration of institutional selection at three Southern Ontario universities. Journal of Further and Higher Education, 42(8), 1143-1155. doi:10.1080/030987 7X.2017.1349889

Minina, E. (2017). 'Quality revolution' in postSoviet education in Russia: From control to assurance? Journal of Education Policy, 32(2), 176197. doi: $10.1080 / 02680939.2016 .1250165$

Mok, K. H. (2015). Higher education transformations for global competitiveness: Policy responses, social consequences and impact on the academic profession in Asia. Higher Education Policy, 28(1), 1-15. doi:10.1057/hep.2014.27

Morley, L., Alexiadou, N., Garaz, S., GonzálezMonteagudo, J., \& Taba, M. (2018). Internationalisation and migrant academics: The hidden narratives of mobility. Higher Education, 76(3), 537-554. doi:10.1007/s10734-0170224-Z
Nikitina, L., Don, Z. M., \& Cheong, L. S. (2016). Construction and validation of a questionnaire on language learning motivation. Zbornik Instituta $\mathrm{Za}$ Pedagoska Istrazivanja, 48(2), 284-300. doi:10.2298/ ZIPI1602284N

Noyes, A., \& Adkins, M. (2016). The impact of research on policy: A case of qualifications reform. British Journal of Educational Studies, 64(4), 449-465. doi: 10.1080/00071005.2016.1159654

Popova, N.G., Beavitt, T.A.(2017). English as a means of scientific communication: Linguistic imperialism or interlingua? Integratsiya obrazovaniya = Integration of Education, 1(21), 54-70. doi:10.15507/19919468.086.021.201701.054-070

Scharager Goldenberg, J. (2018). Quality in higher education: The view of quality assurance managers in Chile. Quality in Higher Education, 24(2), 102116. doi:10.1080/13538322.2018.1488395

Schneider, S., Nebel, S., Beege, M., \& Rey, G. D. (2018). The autonomy-enhancing effects of choice on cognitive load, motivation and learning with digital media. Learning and Instruction, 58, 161-172. doi:10.1016/j.learninstruc.2018.06.006

Siekierski, P., Lima, M. C., Borini, F. M., \& Pereira, R. M. (2018). International academic mobility and innovation: A literature review. Journal of Global Mobility, 6(3-4), 285-298. doi:10.1108//GM-042018-0019

Song, J. (2018). Creating world-class universities in China: Strategies and impacts at a renowned research university. Higher Education, 75(4), 729742. doi:10.1007/s10734-017-0167-4

Strielkowski, W., Kiseleva, L. S. \& Popova, E. N. (2018). Factors Determining the Quality of University Education: Students' Views. Integratsiya obrazovaniya = Integration of Education, 22(2), 220236. doi:10.15507/1991-9468.091.022.201802.220$\underline{236}$

Zainuddin,Z., \& Perera,C. J.(2019).Exploring students’ competence, autonomy and relatedness in the flipped classroom pedagogical model. Journal of Further and Higher Education, 43(1), 115-126. doi:1 0.1080/0309877X.2017.1356916

Zepke, N. (2018). Student engagement in neo-liberal times: What is missing? Higher Education Research and Development, 37(2), 433-446. doi:10.1080/0729 $\underline{4360.2017 .1370440}$ 